\title{
JAARVERSLAG VAN DE CONSERVATOREN OVER 2011
}

\section{Aanwinsten}

- Van de Vereniging

Takeuchi Seiho, Blauwe golf, hangrolschildering inkt en kleuren op zijde, h. 99 cm., br. 35 cm., Japan, 1905 (AK-MAK-1731).

- Van het Rijksmuseum

Parasol met gesneden ivoren handvat, afkomstig van de barones Jacoba Elisabeth Van der Capellen, geboren Van Tuyll, h. 76,5 cm., China, begin $19^{e}$ eeuw (AK-RAK-2011-1).

21 Kimono's (AK-RAK-2011-2 t/m 23). Een toevoeging van Jan Dees aan zijn schenking in 2009.

\section{Restauratie en onderzoek}

Een groep Indiase sieraden werd gerestaureerd, gepoetst en vervolgens (opnieuw) gefotografeerd. Een aantal sieraden bevatte delen die in het verleden verstevigd werden met zwart draad. Deze verstoorden het beeld van het sieraad. Daarbij waren er soms losse parels aanwezig en waren onderdelen vastgezet op een wijze die erg verschilde van de oorspronkelijke

U1 techniek. Op sommige sieraden zat veel zogenaamd 'hanteervet', dat nu verwijderd werd. De volgende sieraden werden behandeld:

AK-NM-7073 borsthanger

AK-NM-7053-A-B paar armbanden

AK-NM-7065 paar schakelarmbanden

AK-NM-7087 enkelbandjes

AK-NM-7057 oorbellen

AK-NM-7059-A-D oorbellen

AK-NM-7088 teensieraden

AK-NM-7054 paar armbanden

AK-NM-7086 halsketting

AK-NM-7056 haarsieraad

AK-NM-7089 enkelbandjes

AK-NM-7062 halsketting

De Koreaanse schildering van een Guanyin (AK-MAK-492) is uit zijn lijst gehaald en als rol gemonteerd door Restorient in Leiden.

De Chinese schildering van een priester (AK-MAK-95) is door hetzelfde atelier gerestaureerd en geconserveerd.

Drie Chinese ivoren stapeldozen uit het begin yan de 19 e eeuw zijn door de restaurator Jan Dorscheid, onder begeleiding van Paul van Duin, hoofd vanaccess 
het meubelrestauratieatelier van het Rijksmuseum, schoongemaakt en gerestaureerd (AK-NM-7006-AB en AK-NM-7023).

Er is een groot project begonnen naar gietmethode en legering van de Dansende Shiva (AK-MAK-187). Op 6 december werd het brons in de röntgentunnel voor zeecontainers van de Rotterdamse douane doorgelicht waarbij bleek dat het brons helemaal massief gegoten is. Ook een aantal zwakke plekken en scheurtjes kon zo in kaart worden gebracht. Verder zijn er 21 monsters genomen van de corrosielaag van het beeld. Deze werden door middel van XRD röntgendiffractie en SEM-EDX (raster elektronenmicroscoop) onderzocht. Dit onderzoek richt zich in eerste instantie op het in kaart brengen van verschillende substanties die op het beeld aangetroffen zijn, de corrosiepatronen en de corrosieproblematiek. Het volledige rapport van het onderzoek wordt mid-2012 verwacht.

Lucien van Valen en Isabelle Garachon hebben het onderzoek naar de karavaan van Chinese paarden en kamelen uit de Tang-periode (AK-MAK66-70) voortgezet.

\section{Tentoonstellingen}

Aan de volgende tentoonstellingen werden werken uitgeleend (alleen de inv.nrs. van voorwerpen van de VVAK worden vermeld):

- 'Kakiemon: meester porselein-makers uit Japan' Keramiekmuseum Princessehof, Leeuwarden, 12 december 2010 - 3 april 2011

- 'Bali, Art, Ritual, Performance' Asian Art Museum, San Francisco, 25 februari - 11 september 2011 (AK-MAK-280)

- 'Handelswaar en Souvenirs - islamitische kunst uit het Rijksmuseum Amsterdam' Rijksmuseum van Oudheden, Leiden, 21 maart - 4 september 2011 (AK-MAK-1250, 1251, 1253, 1256, 1477 en 1484)

- 'Yin en Jan, Nederland en China door scheepvaart verbonden' Maritiem Museum Rotterdam, 2 april 2011 - 4 maart 2012

- '10.000 X happiness, gelukssymbolen op Chinees porselein' Keramiekmuseum Princessehof, Leeuwarden, 29 april - 30 oktober 2011 (AK-MAK-569, 572, 589, 662)

- 'Famille verte, groen geëmailleerd Chinees porselein' Groninger museum, 27 juni 2011 - 20 mei 2012 (AK-MAK-555, 567, 568, 574, 575, 1495)

- 'Uit de kunst, 100 jaar Nederlandse kunsthandel' Paleis het Loo, Apeldoorn, 11 november 2011 - 8 jan 2012

- 'Maanlicht, mysterie en schoonheid: De complexe wereld van prentkunstenaar Tsukioka Yoshitoshi'

Sieboldhuis, Japanmuseum, Leiden, 9 december 2011 - 18 maart 2012

\section{Bezetting van de afdeling}

Op 1 februari 2011 trad William Southworth in dienst van het Rijksmuseum Op de afdeling Aziatische kunst werken nu vier conservatoren. Jan van Campencess 
is conservator voor de Aziatische exportkunst, Menno Fitski is conservator voor de kunst uit Oost-Azië, Anna Slaczka is conservator voor de kunst uit ZuidAzië, en William Southworth is conservator voor de kunst uit Zuidoost-Azië.

\section{Publicaties}

- Jan van Campen

'Masters of the Knife: Chinese carving in wood, ivory and soapstone', The Rijksmuseum Bulletin 59/2 (2011), pp. 152-73.

[met Ebeltje Hartkamp-Jonxis], Aziatische Weelde: VOC-kunst in het Rijksmuseum / Asian Splendour; Company Art in the Rijksmuseum, Walburg Pers, Zutphen, 2011. [Uitgave in samenwerking met het Rijksmuseum, Amsterdam] 'Straks weer te zien: de pagode van Royer', Aziatische Kunst 41/4 (2011), pp. 37-40.

\section{- Menno Fitski}

Kakiemon Porcelain: A Handbook, Leiden University Press en Rijksmuseum, Amsterdam.

'Straks weer te zien in het Rijksmuseum: een jaden cong', Aziatische Kunst 41/2, pp. 24-5.

'Portraits of Chôgen. The Transformation of Buddhist Art in Early Medieval Japan', boekbespreking, Andon 90, pp. 67-70.

\section{- Anna Slaczka}

'The iconography of the deities in the Devyâmata, an early Shaiva pratishthâtantra, and the art of Bengal', Journal of Bengal Art 16 (2011), pp. 157-67.

'Temple consecration rituals in the Hindu tradition of South and Southeast Asia. A study of the textual and archaeological evidence', in: Piotr Balcerowicz en Karl Potter (eds.), Art, Myths and Visual Culture of South Asia, Motilal Banarsidass, Delhi, 2011, pp. 99-113.

'The depositing of the embryo' - Temple consecration rituals in the Hindu tradition', in: Pierre-Yves Manguin et al. (eds.), Early Interactions between South and Southeast Asia. Reflections on Cross-Cultural Exchange, Institute of Southeast Asian Studies, Singapore, 2011, pp. 429-38.

'Dancing Siva images from Bengal', in: 'Pranatattva'. Dr. M. Harunur Rashid Commemoration Volume, Dhaka, [2012] (in press).

'The two iconographic chapters from the Devyâmata

(Nisvasakhyamahatantra). Edition of the Sanskrit text on the basis of available manuscripts, English summary and the comparison with the art of Bengal', Tantric Studies [2012] (artikel geaccepteerd voor publicatie). 'The brick structures of Go Thap (Vietnam): tombs or temples?', Bulletin of the Indo-Pacific Prehistory Association [2012] (in press).

'Review of: Residential Architecture in Bhoja's Samarânganasûtradhâra: Introduction, Text, Translation and Notes. By F. Otter. Delhi: Motilal Banarsidass, 2010, pp. 298, 12 figures', Indo-Iranian Journal (in press). 'Tentoonstelling Handelswaar en Souvenirs - islamitische kunst uit het Rijksmuseum Amsterdam', Aziatische Kunst 41/2 (2011), pp. 30-5. 'Straks weer te zien in het Rijksmuseum. Godin die de buffeldemon doodt', Aziatische Kunst, 41/3 (2011), pp. 18-20.

'Ik heet geen Nandi! Nogmaals over de stier van Siva' ${ }_{B}$ Aziatische Kunst, 4 1/44: $16 \mathrm{PM}$ (2011), pp. 26-36. 
- William A. Southworth

'River settlement and coastal trade: Towards a specific model of early state development in Champa', in: Tran Ky Phuong en Bruce M. Lockhart (eds.), The Cham of Vietnam: History, Society and Art, NUS Press, Singapore 2011, pp. 102-19.

[met Arlo Griffiths] 'Études du Corpus des Inscriptions du Campa II. La stèle d'installation de Sri Adidevesvara: Une nouvelle inscription de Satyavarman trouvée dans le temple de Hoà Lai et son importance pour l'histoire du Panduranga', Journal Asiatique 299/1 (2011), pp. 271-317.

\section{Lezingen}

- Jan van Campen

'Porcelain in the Dutch interior', lezing op de workshop '17th Century porcelains for the Netherlands', Leeuwarden, 12/13 mei

'Bijzondere bestellingen', lezing ter gelegenheid van de presentatie van het boek Aziatische Weelde, Spui 25, Amsterdam, 11 oktober

- Menno Fitski

"Old coloured Japanese porcelains of the first class": trade and collecting of Kakiemon porcelain', Oriental Ceramic Society, London, 1 februari 'Japanse boeddhistische sculptuur', uitgeverij Brill, 6 februari

'Kakiemon: Meester-porseleinmakers uit Japan', Vrienden Keramiekmuseum Princessehof, Leeuwarden, 13 februari

'Hokusai', Vereniging voor Japanse Kunst, Sieboldhuis, Leiden, 20 februari

'Keramiek voor de Japanse theeceremonie', college Universiteit Leiden, 20 april

'Kakiemon porcelain at the court of William III', Seminar Chinese and Japanese porcelain for the Netherlands in the 17th century, Fries Museum, Leeuwarden, 13 mei

'Kakiemon and the trade in Japanese porcelain', workshop Material Encounters of the East India Trade 1600-1850, Ashmolean Museum, Oxford, 1 juni

'Kakiemon porcelain and Chinese influence, Southeast Asian Ceramic Society, Kuala Lumpur, 31 juli; Singapore Society for Chinese Ceramics Studies, Asian Civilisation Museum, Singapore, 5 augustus; Indonesia Ceramic Society, Jakarta, 8 augustus

'Kakiemon porselein', Stichting Twickel, Twickel, 30 maart; Bornse Synagoge, Borne, 17 oktober

'Kakiemon porselein: datering, productie en receptie', Nederlands Genootschap voor Japanse Studiën, Leiden, 9 december

\section{- Anna Slaczka}

'The iconography of the deities in the Devyâmata, an early Shaiva pratishthattantra, and the art of Bengal', 9th International Congres of Bengal Art, Dhaka, Bangladesh, 7 februari

'Temple Consecration Rituals in temples of South and Southeast Asia', National Institute of Advanced Studies, Bangalore, India, 28 februari 'The importance of unedited Shaiva manuscripts for the study of Hindu iconography', École française d'Extrême Orient, Paris, France, 16 mei

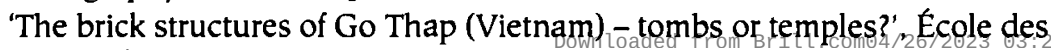
Hautes Etudes en Sciences Sociales, Paris, France, 17 mei 
'South Indian bronzes at the Rijksmuseum, Amsterdam', Universiteit Leiden, Leiden, 8 juni

'Aziatische kunst in het Rijksmuseum', lezing voor delegatie TATA Steel, Rijksmuseum, Amsterdam, 11 augustus

- William A. Southworth

'The Vereniging at Angkor: Sculptures from Cambodia', presentatie voor de Vereniging van Vrienden der Aziatische Kunst, Geelvinck Hinlopen Huis, Amsterdam, 8 oktober

'Iconoclasm and temple transformation at Angkor from the 13th to 15th centuries', lezing conferentie, In the shadow of the Golden Age: Art and identity from Gandhara to the modern age, University of Bonn, 14 oktober

\section{Nevenactiviteiten conservatoren}

- Jan van Campen

lid keuringscommisie TEFAF Maastricht (Aziatische exportkunst)

lid keuringscommissie PAN Amsterdam (Aziatische kunst)

\section{- Menno Fitski}

voorzitter van de Vereniging voor Japanse Kunst

lid van het bestuur van het Nederlands Genootschap voor Japanse Studiën lid van het bestuur van de Hulsewé-Wazniewski Stichting lid van de redactie van het tijdschrift Aziatische Kunst lid van het bestuur van de Stichting für Elise lid van het bestuur van de Stichting Tikotin lid van het bestuur van de Stedenband Leiden-Oxford

- Anna Slaczka

lid van de redactie van het tijdschrift Aziatische Kunst

- William A. Southworth

lid van het bestuur van het project Corpus des Inscriptions du Camp van École Française d'Extrême-Orient, Jakarta 


\section{Vereniging van Vrienden der Aziatische Kunst}

www.vvak.nl

ERELID

Dr. J. Fontein

BESTUUR

Mr. J.M. Boll, voorzitter

Ir. A.A. Holst, lid

Mw. drs. R.H.M. van der Poel, secretaris

Mw. drs. R.E. Roskam, lid

Drs. H. Schulte Nordholt, lid

Drs. T.T. Wen, penningmeester

RAAD VAN ADVIES

Mr. W.L.J. Bröcker

Prof.dr. C.J.A. Jörg

Drs. H.E. Kreijger

Mr. E.M.W. de Lange

Mr. drs. A. Ott

J. Polak

Mw. dr. C.E. van Rappard-Boon

J.J.N. Rost Onnes

Mw. dr. R.L. Steenbergen

CORPORATE MEMBER / SPONSOR

Ottema Kingma Stichting Leeuwarden

International Institute for Asian Studies (IIAS)

\section{Lidmaatschap}

- Gewoon lidmaatschap: $€$ 60,- per kalenderjaar

- Jongerenlidmaatschap ( $\mathrm{t} / \mathrm{m} 25$ jaar): $€ 25,-$ per kalenderjaar

- Sponsor/corporate member:

(tenminste) $€ 600,-$ per kalenderjaar

Het lidmaatschap van de Vereniging loopt van 1 januari tot en met 31 december. Opzegging van het lidmaatschap kan alleen schriftelijk via het bestuur (vvak@denboerenvink.nl). Opzegging voor een komend jaar dienen vóór 31 december van het lopende jaar door het bestuur ontvangen te zijn. Wanneer het lidmaatschap in de loop van het verenigingsjaar wordt beëindigd, blijft de bijdrage voor het hele jaar verschuldigd.
Als WVAK-lid

- ontvangt u vier maal per jaar het tijdschrift Aziatische Kunst

- krijgt $u$ ieder kwartaal de VVAK-Nieuwsbrief ir de bus

- wordt u uitgenodigd voor lezingen en bijeenkomsten

- krijgt u een lidmaatschapskaart, waarmee u gratis toegang heeft tot het Rijksmuseum Amsterdam en de activiteiten van de VVAK

\section{Ledenadministratie en secretariaat Vereniging} Jac's den Boer en Vink bv

Postbus 43

2850 AA Haastrecht

T: 0182501696

E:vvak@denboerenvink.nl

\section{Advertenties}

Om te adverteren in Aziatische Kunst kunt $u$ contact opnemen met de heer drs. T.T. Wen, penningmeester, e-mail: wentt@xs4all.nl

\section{Bankrekeningnummer}

ING 188285 , ten name van Vereniging van Vrienden der Aziatische Kunst, Den Haag.

\section{Kamer van Koophandel}

De Vereniging is ingeschreven bij de Kamer van Koophandel in Amsterdam, onder nummer 40.531.260.

\section{ANBI}

De Vereniging heeft de status van een Algemeen Nut Beogende Instelling. 